\title{
FROM GENDERING TO INTERSECTIONAL LABELLING. RUSSIAN AND SWEDISH POLITICAL JOURNALISTS' PERSPECTIVE ON DISCRIMINATING AND PROMOTING MECHANISMS IN THE MEDIA CONTENT $^{1}$
}

\author{
AUTHOR: VORONOVA, Liudmila \\ Lecturer - University of Gävle - Sweden \\ lusyandrik@gmail.com
}

\begin{abstract}
This paper suggests to study the phenomena of gendering in political journalism from intersectionality perspective (Davis, 2008; McCall, 2005) in order to understand gendering in the framework of other discriminatory and promoting mechanisms in political news. Gendering is understood as the perceived imprint of gender on the media portrayal of politics and politicians, as well as the processes whereby gendered media representations materialize (Voronova, 2014). The paper is based on forty semi-structured interviews with political journalists working for the quality press in Russia and Sweden. The choice of the countries is driven by the wish to explore the difficulties and similarities of the journalists' conceptualizations of gendering and other discriminatory and promoting mechanisms in two very different political and cultural contexts. The paper shows that the journalists in both countries highlight the importance of not only gender mainstreaming, but diversity in the content as a democratic
\end{abstract}

value, where gender stands in the same row with other difference-making categories (such as ethnicity, sexuality etc.). The paper highlights the difficulties and contradictions the Russian and Swedish political journalists face trying to achieve their diversity ideal. The paper suggests a definition of intersectional labelling in political journalism, and proposes that it is an ambiguous process, which can be either discriminatory or promoting, depending on its manifestations. Moreover, its application is contextual, and is related to the journalists' vision of ethics, commercial benefits of the media organization, and press freedom.

\section{Key words}

gender; intersectionality; journalism culture; matrix of domination; political journalism.

\section{Introduction}

Recognized as a holder of power with a social responsibility to respect gender equality, the media ideally should promote an idea of equal possibilities for everyone in the society and of equal access to political power (Falk, 2008; Ross, 2002; Getting the Balance Right, 2009; Recommendation CM/Rec, 2013; Mission Possible, 2008). Yet, according to Gill (2007: 114), the media, and specifically news reconstruct the dominant cultural assumptions, which are determined by race, gender, class, wealth, power and nationality.
This "matrix of domination" (Collins, 2000) is more and more often approached in media and

\footnotetext{
${ }^{1}$ This paper is based on the material of my doctoral study titled "Gendering in political journalism: A comparative study of Russia and Sweden" (Voronova, 2014). The paper suggests a broader approach to the research problem than in the published dissertation and makes a re-reading of the materials applying the perspective of intersectionality. Unpublished materials from the study are added. An incomplete version of the paper was presented at the European Conference on Politics and Gender (Uppsala, 2015, 11-13 June).
} 
communication studies with the help of intersectional approach (Davis, 2008; McCall, 2005). Intersectionality in various disciplines proposes tools to analyze the overlapping and conflicting power differentials and normativities of the different inequalities (Lykke, 2010: 50-51, referred to in Hultén, 2015). According to Lünenborg and Fürsich (2014: 960), in media and communication studies, "intersectional analysis assesses the links between different dimensions of inequality identifying media as an important contributor to the construction of social hierarchies". The intersectional approach is challenging due to the problems of translating and accommodating the concept in different contexts (Rigoni, 2012), the additive perspective - when categories are viewed as just an addition to gender, or one another (Roosvall \& Widestedt, 2015), and risks of creating and fixing an Other in the process of the research itself (Lünenborg \& Fürsich, 2014). Moreover, there is a lack of definitions that would allow the scholars to discuss the processes by which the media contribute to building the "matrix of domination" in a given context or challenge the existing hierarchies. Yet, there is a need for more discussions of intersectionality and the interplay of media, politics and democracy (Fiig et al., 2015).

This paper aims to map some of the discriminatory and promoting mechanisms in political news related to intersectionality, by giving voice to the Russian and Swedish political journalists working for the socalled "quality" press. I wonder how the journalists understand the mechanisms of "gendering" and other related discriminatory and promoting mechanisms, and what they see as the reasons for political news employing the categories of gender, nationality, ethnicity, and sexuality when othering or promoting foreign and domestic politicians and policies. I suggest to use the concept of intersectional labelling in political journalism as an overarching term for a perceived imprint of the intersection of categories of gender, race, ethnicity, sexuality, age etc. on the media portrayal of politics and politicians, as well as the processes by which such representations materialize. I suggest to view intersectional labelling as not a necessarily discriminatory practice, but as a more complex process that has a potential for promoting certain groups of citizens or politicians, and mainstreaming diversity through the critique of the existing intersectional hierarchies.

The paper proceeds as follows. I will first introduce the reader to the material and the methodology of the research. I will then present the Russian and Swedish journalists' views on gendering and intersectional labelling, presenting the themes that resulted from the analysis and paying attention to the contexts where the journalists produce political news. Further on, the paper discusses applicability of the findings related to gendering to intersectional labelling as a broader, overarching process. The paper concludes by discussing the relation of this process to the contextual understanding of ethics, press freedom and commercial benefits by the journalists.

\section{Methodology}

This paper is based on the materials collected for my doctoral study (Voronova, 2014). I conducted forty semi-structured interviews with political journalists involved in the production of articles in the so-called "quality" press in Russia and Sweden. With the focus on intersection of such categories as gender, nationality, ethnicity and sexuality, this paper seeks to close the gap acknowledged by me when writing the dissertation focusing on the mechanisms of gendering alone, where gendering was understood as the perceived imprint of gender on the media portrayal of politics and politicians, as well as the processes whereby gendered media representations materialize (Voronova, 2014). The discussions with the journalists were not directly addressing the other axes of the "matrix of domination" discussed in the framework of intersectionality theory. However, in the interviews with both the Russian and the Swedish journalists, other than gender vectors of oppression and privilege were often addressed by the journalists themselves. Thus, my focus on gender as a single analytical category put limitations on 
the understanding of the discriminatory and promoting mechanisms in political news, as the interviewed journalists themselves talked about diversity in journalism as a vital democratic value (cf. Jönsson, 2004), understanding the categories of gender, ethnicity, race, physical capability etc. in their mutual interaction as it is suggested within intersectionality perspective (Davis, 2008; McCall, 2005).

The interviews were conducted in 2011-2012. The quality press is referred to as a specific segment of the printed media. The media that position themselves as "quality brand", (Anderson, Ogola and Williams 2014), promise readers a certain quality of journalistic product: pluralism of opinions, reliability of facts, and non-biasness. The quality press, thus, becomes a "preferable terrain for the public dialogue” (Voinova, Resnyanskaya \& Khvostunova, 2007: 83, my translation). Unlike the popular press, quality outlets view their readers as citizens rather than consumers (Hanitzsch, 2011). The quality press can be considered among the most influential actors of political communication, being an important intermediary between the potential voters and the political sphere (Ross, 2010). The Russian outlets included: Kommersant, Kommersant.Vlast', Novye izvestiya, The New Times, and Forbes. The Swedish outlets included in the sample were Dagens $\mathrm{Ny}_{\text {- }}$ heter, Svenska Dagbladet, Fokus and Veckans Affärer.

Russia and Sweden appear as very different contexts when it comes to both achievements in the sphere of gender equality and media models. Russia ranks $75^{\text {th }}$ place (out of 142 countries) when it comes to the political empowerment of women, and Sweden is at the 4th (Global Gender Gap Index, 2014). Sweden is considered a "feminist state" (Bergqvist, Adman \& Jungar, 2008) with a "passion for equality” (Holli, Magnusson \& Rönnblom 2005; Inglehart \& Norris 2003), and a considerably, long history of fighting, for gender equality (Bergqvist, 1999; Freidenvall, 2006; Karam, 1998). Sweden promotes gender equality policies and is considered to be at the top of the list when it comes to gender equality achievements (Djerf-Pierre, 2011). However, some scholars see a problem with putting gender equality into practice (Holli, Magnusson \& Rönnblom, 2005; Osika, 2008).
In Russia, political power has remained one of the most impermeable "ceilings" for women (Zdravomyslova, 2003). The everyday practices of women and men here since 1991 have been defined by the "patriarchal renaissance" (Posadskaya, 1993; Kay, 2007). The recent years saw an increase of traditionalism and "politicization of gender in the last decade of Putin's Russia" (Temkina and Zdravomyslova, 2014), with the scandal around the punk group Pussy Riot, and the enactment of the law forbidding "propaganda of homosexualism among youth and children".

When it comes to the media models, both Russian and Swedish media systems are often viewed as systems in transition. The transformation of the media in Russia was characterized by a gradual narrowing down of the media influences and freedoms (Koltsova, 2001; Voinova, Resnyanskaya \& Khvostunova, 2007; Voltmer, 2013; Zassoursky, 2004). The today's media system in Russia is defined by Vartanova (2013) as the governmentcommercial Eurasian model, synthesizing "European" and "Asian" characteristics of media worlds, with the media playing a role of an "obedient child" of the state. Logic of commercialization here is combined with an authoritarian approach by the government (Pasti \& Nordenstreng, 2013). The tight control over the major media is implemented through financial and political control of its owners and administrative and economic control of journalists (Voinova, Resnyanskaya \& Khvostunova, 2007). Nearly half (46.8\%) of all the Russian journalists believe that the level of press freedom in the country has decreased in the last 5-10 years (Anikina \& Johansson, 2013).

The Swedish media system is viewed as the Democratic Corporatist Model (Hallin and Mancini, 2004) turning into the Liberal Model (Allern and Blach-Orsten, 2011; Wiik, 2014). This transformation is characterized by increasing commercialization and, thus, a dependency of journalism on the market rather than the state (Allern \& BlachOrsten, 2011; Dahlgren, 2000; Ekecrantz, 2005). The journalists suppose that there is a near-zero political influence on media content (Nygren \& 
Appelberg, 2013), and the scholars suggest that the news media compete with the political parties in their influence (Allern \& Blach-Orsten, 2011; Strömbäck, 2009).

The journalists' perceptions of their roles and practices constitute an important object of studies, allowing to better understand the processes both inside and outside of the media (Hanitzsch et al. 2010). The major focus of the paper is on the journalists' own conceptualization of gendering and of what I label in the paper as intersectional labelling. That's why I chose the ethnographic approach, meaning that it is the journalists' ideas and views that have become central to the analysis (Löfgren Nilsson, 2010; Lindlof \& Taylor, 2002). Theoretical construct sampling (Lindlof \& Taylor, 2002) was combined with snowball sampling (contacts of other potential informants were received from the interviewees). Reporters and editors were chosen as the key informants, as these are the most common professional roles occupied by journalists (e.g. among all Russian journalists $53.4 \%$ work as reporters, and $31 \%$ fulfill the roles of editors - Anikina \& Johansson, 2013). Additionally, I interviewed Russian and Swedish media experts - scholars, employees of the national unions of journalists, and editors of professional magazines for journalists.

Political journalism not only covers predominantly men, but also is still dominated by male reporters and editors (van Zoonen, 1998; Djerf-Pierre, 2007; Gallagher, 2005; Klaus, 2009; Löfgren Nilsson, 2010). Among the Russian interviewees there were 7 women, and 14 men. This misbalance was influenced by the representation of women and men in the political and international departments of the outlets chosen for this study at the moment of the field-work, and the way the interviewees were giving recommendations on whom of their colleagues to contact further. Among the Swedish interviewees there were 10 women and 9 men. The quantitative superiority of female interviewees does not correspond to the existing data on the amount of women and men covering political issues (according to the Global Media Monitoring Report, 2010, there are only $37 \%$ of news on political issues reported by women). Here the results of the sampling can be explained first and foremost by the way the professional networks function: unlike in the Russian case, both female and male interviewees in Sweden, tended to give me contacts of their female colleagues in the process of snowball sampling.

The interviewed journalists in this paper are anonymous, while the names of the media experts are provided. The interviewed journalists signed a consent form and were sent the transcriptions of the interviews. They could refuse participation in the study at any time. I do not identify the journalists' place of work, as the interviewees many times pointed to the fact that there is a common culture of quality political journalism in their country, and that other quality outlets have similar approaches to theirs. However, the journalists' positions are provided (the mentioned positions were valid for the time of the interview) in order to specify the kind of tasks the journalist undertakes in political communication, as this proved to be important for the analysis. The interviews in Russia were conducted in Russian language, and excerpts from them were translated by the author. The interviews in Sweden were conducted in English language, and the grammar and stylistic mistakes were edited in the excerpts.

The interviews were transcribed and read as texts (van Zoonen, 1994). The empirical data was the starting point in the analysis. The data was sorted into categories, and labeled theoretically (Jensen, 2002).

\section{Results and discussion}

According to the journalists, the quality press is unique in terms of the ideology that the journalists belonging to this specific culture of political journalism should follow. As such, the journalists suggest the representation of the world in its diversity is one of their primary aims. In the words of one of the Swedish journalists, 
It's important for the whole society [that the media content has gender equality]! I mean, equality - not only between sexes, but between people. And when you are in media, you have a certain responsibility to do this, because you are supposed to reflect society, and a lot of people - their image of the society is from media, so it is very important ( $\mathrm{T}$, political reporter, male, Sweden).

This focus on the equality between people, rather than between sexes only, suggests an interpretation of gender balanced media coverage that goes along the same lines as what media experts suggest: gender balanced media coverage should be understood broader, as a diverse and unbiased media output, which reflects and informs public opinion and dialogue supported by editorial policies (Mission Possible, 2008).

\subsection{Intersectionality and media ethics}

The editorial policies of the quality press in Russia and Sweden are very similar when it comes to diversity and gender balance in the content. In many ways, it is connected to the fact that the International Federation of Journalists (IFJ) has for many years worked with the national unions of journalists on improving the practices of journalistic work when it comes to publishing unbiased and balanced materials. According to a survey conducted by the IFJ in 2001, most of the IFJ member unions in the world have adopted codes of conduct or practice defining ethics in journalism that include a clause with a call to professionals not to publish materials discriminating against persons on the basis of race, sex, religion or ethnicity (Peters, 2001). Moreover, all of the IFJ member unions have signed the IFJ Principles on the Conduct of Journalists, which states in paragraph 7 that:

The journalist shall be aware of the danger of discrimination being furthered by the media, and shall do the utmost to avoid facilitating such discrimination based on, among other things, race, sex, sexual orientation, language, religion, political or other opinion, and national or social origins (Peters, 2001: 15).
In Russia, two statutes of the Code of Ethics for Russian journalists restrict the creation of imbalanced content in journalism. One of them states that it is a professional responsibility of a journalist to counteract extremism and limitations of civil rights in relation to sex, race, language, religion, political and other views, as well as social and ethnic background. Another one calls for abstaining from any disregarding hints or comments in relation to race, nationality, religion, social background, or sex, as well as in relation to physical defects, or illnesses (Code of Ethics, 1994).

The editorial policies concerning keeping to the ideal of gender- (and other intersectional categories) neutral journalism that complement the Code of Ethics of the Russian journalists are strict and leave no space for any frivolousness or jokes when it comes to the intersectional characteristics of politicians. Anything that doesn't meet the quality journalism requirements should be restricted, even if the journalist wants to highlight specific categories as positive features. For example, one interviewee wrote about a session in the European Parliament, where one of the parliamentarians made what the journalist found to be a very clear and interesting statement. This parliamentarian happened to be the only transsexual person in the European Parliament. As the journalist commented,

Honestly, I so much wanted to capture the atmosphere, and I had a will to write that the brightest quotation in this discussion came from this whether a woman, or a man - well, at least specify it for the reader. But the editor set strict limits: no giggling, no hints to the transsexual story, we just represent her. I asked: “So, do we write 'he' or 'she'?” And the editor said: "What is written on the European Parliament's website?" I said: “She." “That's it, that's what we write, no insinuations" (L, international reporter, female, Russia).

In Sweden, the first laws forbidding discrimination based on sex were adopted already in the 1970s, and in 1972 the National Council for Equality between Men and Women was formed, followed by the Ombudsman for Gender Equality and the Commission for Gender Equality (1980). Today the overall tendency in Northern Europe can be 
described as subordinating concerns for gender equality to concerns for diversity (where the intersection between gender, ethnicity, religious affiliation, age etc. stands at the core of the approach) (Widestedt, 2008). This tendency is noticed by the journalists themselves. As one of the interviewees noted,

I think that the gender discussion comes more naturally now, it is more implemented already in how we think. So maybe we don't need to discuss that, as much as, for example, class or ethnicity. I think, there is a bigger problem with these [latter] issues than with the gender issue, because we've had knowledge about that [gender] for a long time... Ah, not knowledge, but we've been aware of this issue for a longer time. So, I think, that might come more naturally now. But I think it's [gender] still something that is discussed, [and] maybe you don't need to discuss it that much (M, political journalist, female, Sweden).

Following this trend in 2009 goals of ombudsmen for different types of discrimination were consolidated under the roof of the Ombudsman against discrimination (Diskrimineringsombudsman), and a new law, The Law against Discrimination (2009), was introduced. The law is aimed to confront discrimination, e.g., in the workplace and in professional careers, in education, in health care, in organization membership and in social services. While it covers almost all spheres of social life, it cannot regulate the media content, as the media regulation acts Tryckfrihetsförordningen/The Freedom of the Press Act (1949) and Yttrandefrihetsgrundlagen/The Fundamental Law on Freedom of Expression (1991) - defend the media against interference with the production of content. According to Swedish researcher Maria Edström, this conflict highlights the necessity of a well-developed system of self-regulation (interview with Edström from October 5th, 2009).

One of the most important guarantees for gender balance in the journalistic content is the Code of Conduct for Swedish journalists, which tells journalists not to focus on the ethnicity, gender, religious affiliation, political view, sexual orientation of the person covered in the article if it is not relevant in the context and if it is disrespectful
(Code of Conduct, n.d.). Many of the journalists suggest, however, that there is a need to go further and pay a special attention to diversity in media coverage. For example, one of the interviewees initiated an intense discussion of diversity in the content at her previous place of work by creating a so-called "Diversity group" (Mångfaldsgruppen) within the newsroom. This example is important, insofar as it shows that the Swedish journalists are themselves initiating changes in the standards of coverage, apart from the general rules and selfregulatory standards. This allows them to avoid unwanted top-down initiatives, when the standards would be changed by other actors. Moreover, this defends the journalists from criticism from the readers and subjects of news stories:

It was me, and the editor-in-chief, and 5 or 6 other reporters, so we discussed these things a lot and we analyzed the newspaper and said: "Well, ok, this is how we write about Muslims, this is how we write about women, this is a problem, this is what we need to learn" $[\ldots]$ We made a plan: this is the way we write about that, this is what you should think about... And everyone has that plan now - everyone who works in the newspaper... Just, yeah, quite normal things like what to do and what not to do (S, political reporter, female, Sweden).

Thus, intersectionality is addressed by the ethical codes and editorial policies in both countries, and the journalists are well aware of the existing norms and recommendations. Many of them are keen on producing diverse and unbiased content, and in Sweden, the journalists even take the initiative to improve the content based on the ideal of diversity.

\subsection{Intersectionality as a problem}

In Sweden, however, some of the media experts and the journalists themselves suggest that the achievements of diversity in the content are disputable. The journalists claim that when magazines and newspapers try to produce diverse output, they do get the voices of women, immigrants, and other underrepresented groups, but then these people often "only get to talk about what it feels to be an immigrant, what it feels to be a woman, and not the things that they do" (S, political reporter, female, Sweden). Another 
problem is formulated by Axel Andén, editor of the professional magazine Medievärlden [Media World] (Sweden):

Most companies have policies that they should work for equality or diversity, or that they should try to represent men and women equally, and also have people with other ethnic background. [...] But they don't go as deep as how the texts are representing equality. I think, they... the first level is that they just count men and women. If they go deeper, they count like - if this is people in power, if this is people in the street - you know, what category they come from. But I don't think that they go as deep as to analyze the text and the context itself. And I don't know if that could be done either (Interview with Axel Andén from November 11th, 2011).

In Russia, the interviewees named other problems and challenges that the journalists face when trying to fulfill the ideal of diverse media content. First and foremost, it is the homogeneity of the political sphere represented mainly by middle-aged men. According to Vladimir Kasutin, Secretary of the Russian Union of Journalists and chief editor of magazine Zhurnalistika i mediarynok [Journalism and Mediamarket], something should be done to the journalists' passive expectation for changes, whereas they expect that something should first happen within the political sphere and in the society, and only then in the media:

In the recent years in Russia, in many areas there has happened a backlash. [...] Despite the fact that journalism in Russia has become "female", because today more than $80 \%$ of the media employees are women, yet somehow [...] too many journalists go, and, if there are men in power, they write about them, so they do not reflect upon, they do not estimate the amount of stories' actors, what should be monitored: that different groups of population are equally represented, both different ethnic groups, and women, men, and old and young people. It is mainly one and same people, who appear on the pages and screens: middle-aged men, working either in the government or business, and others are less represented. Why? Because they [these men] are either more active, or they have money, or they can either force, or pay, or convince. But there are no meaningful attempts of journalists to attract somewhat different people to their pages (interview with Kasutin from December 28th, 2011).
Similar problem is, however, named also by the Swedish political journalists. Despite the journalists' willingness to create intersectionally diverse media content, the sphere that they are supposed to cover is not as diverse and heterogeneous as they wish it to be. Be it politicians, or ordinary citizens making "everyday" politics, the journalists are much more likely to find a middle-aged man to step forward and make his voice heard through the newspaper or magazine:

I actually think that it is more difficult for a woman to be seen as a prime minister or a candidate - in Sweden as well! I mean, it is male, heterosexual, middle-aged people who are... Males, white males who are elected - presidents, prime ministers, and so on! (L, political observer, female, Sweden)

The strategy of [our] paper is to have a mixture of all ages and genders [in the content]. Then different departments have different difficulties. We have this difficulty, for instance, that I could say to someone of the correspondents in Kabul: you should interview a woman, and he can come back and say: "Today it was not possible. I could not get an ordinary woman to interview today. I have to work in another way, I have to make contacts, it takes days, they have to trust me. I have to go back with a woman. I first have to speak with the men”. [...] And my way of working with it is to say to all correspondents that we would like to have both men and women, and since there are so many men, they will come automatically to the paper, so we have to find women (P, editor of international department, female, Sweden).

The Russian journalists name one more problem that they face when trying to create diverse content: surviving on the media market. They believe that all the media in Russia, including the quality newspapers and magazines, are challenged by the tendency of tabloidization, and the requirements that the market dictates. Though pointing to the fact that some categories (such as race) are not as problematic as other (such as gender), these critical voices state that certain rules should be formulated in order to guarantee that quality journalism remains diverse and neutral in the current situation:

The main thing is to draw attention by, I don't know, a picture, or a special image, which always draws attention. There is a tendency to push this [the spotlighting of gender and emphasizing differences between women and men]. A lot of time should pass 
before in relation to women there will be the same law, well, not a law, but an unwritten rule, which now works in relation to ethnic minorities. For example, in the US, in an article about Barack Obama most often it isn't mentioned that he is black. So if you do not watch TV, if you don't see his speeches, and if you didn't see the first reaction concerning the election of the first black president of America, then today from the articles we read no one could guess this [that Barack Obama is black]! This topic has gone away [from the media agenda]. When it comes to women, I think that so far it will remain, and even will be pushed [due to the requirements of the market] (N, head of international group, male, Russia).

Thus, both the Swedish and the Russian journalists see production of intersectionally diverse content as problematic, yet very important. They point to various problems, some of them being universal (such as domination of white, middle-aged men in the political sphere), and other contextual (such as the rules of the media market and visibility of certain categories of the "matrix of domination"), yet, the journalists working for the quality press are trying to find the ways to strive for what they see as one of the ideals - diverse and unbiased media output.

\subsection{Intersectionality and critique of the political sphere}

There is, however, one more reason why the journalists still stick to gendering and other "-ings" the need to criticize politicians, whether domestic or foreign. The Russian journalists admit that women politicians are more often subject to gendered critique in the media discourses than men (cf. Braden, 1996; Falk, 2008; Norris, 1997; Ross, 2002; Sreberny-Mohammadi \& van Zoonen, 2000). For example, one of the interviewees told me about a situation that she observed, where her colleague from another Russian outlet criticized a foreign politician "between the lines" by applying gender stereotyping, which the interviewee considered to be a dishonest method:

[M]y colleague from another big media - when [Hillary] Clinton was presenting in Vilnius about the OSCE, and she strictly said that our elections are unfair and unjust - wrote something like "Hillary
Clinton with her thin pony tail." Announcing the quotation this way he, clearly, disavows everything she said. 'Cause it already doesn't matter what she said, does it? Even if she would say the very truth, this "thin pony tail" is an image, which crosses out all the rest (L, international reporter, female, Russia).

In this case, the intersection of the categories of nationality and gender fed into the "double othering" of a foreign female politician. The interviewee emphasized, however, that she herself would never describe any politician in such a way; neither the editorial board of her outlet, nor her personal ethical limits would allow her to apply such stereotypes.

Interestingly, the Russian male journalists find stereotypes to be a tool for establishing relations with the readers through what they find to be humoristic or ironic. This correlates with the observed tendency that in the Russian context male media producers hold the power to make jokes (Kalinina \& Voronova, 2011). Indeed, the codes of humor are efficient if they are shared by the one who makes a joke and the one who receives it, and conceiving humor as a discourse leads to recognition of it as depending greatly on its immediate social context (Crawford, 2003). Moreover, these jokes in the Russian media content tend to draw on and feed into traditional stereotypes, ridiculing those who are considered "other" in comparison to the heterosexual masculine norm: women (especially active), and homosexual and elderly men (Kalinina \& Voronova, 2011). Politicians of both sexes, or, rather, their alleged inability to fulfill the public expectations of femininity and masculinity, becomes a focus of the journalists' irony. As one of the interviewees commented on the article he wrote himself (in coauthorship),

There had been a lot written about elections already, so we needed to write something else. We decided to access it from another side: [...] the role of sexual scandals in the forming of the public image, the role of sexual aspects in political image building and advertising [...] This is funny, I read here: "While men in politics run a risk of impotence and homosexuality, the few women lose their femininity...” (K, editor of news department, male, Russia). 
Homosexuality of politicians, especially male, becomes, according to the Russian journalists, a convenient arena for the journalistic critique. According to the Russian journalists, politics in Russia can be considered conventionally masculine: not only because of the amount of women and men being inhabitants of the political culture, but mainly because of the traditions of this culture, specific mechanisms, which require that politicians follow culturally set patterns of self-presentation and their party's image, which are to a big extent based on existing in this culture gender codes. These codes, in their turn, define not only the way politics works, but also the way it is covered by the media:

I remember that I was writing one article about perception of men and masculinity, and one of the experts told me that, for example, in Scandinavia if a politician looks so that it is not possible to understand if he is gay or not, he is absolutely accepted. Here in Russia it would not work. One political scientist suggested an example: when Yavlinsky ${ }^{2}$ in 1999 was a candidate in the elections, his opponents organized in Moscow a demonstration of the sexual minorities in support of him. So, it was a "black PR" [campaign]. There were gays and lesbians, with rainbow flags and placards "We support Yavlinsky". It was broadcast on TV, something like: "Look there! That's who support Yavlinsky!" And in Scandinavia, politicians often themselves hire agitators among representatives of the sexual minorities in order to show that "I am tolerant", "gays and lesbians support me as well” (K, editor of news department, male, Russia)

The theme of the specificity of the space, where the Russian culture of political journalism is situated, was a common refrain in the journalists' reflections upon the reasons and the roles of intersectional labelling in the content of the Russian political journalism. The "in-betweenness" of Russia, located, according to the journalists, between Europe and Asia, makes them constantly re-evaluate the standards and requirements of journalism. As one interviewee told, it becomes almost impossible to write any insinuations about sexuality of the

\footnotetext{
${ }^{2}$ Grigory Yavlinsky was the leader of the liberal party "Yabloko" in 1993-2008. He is now active as one of the leaders of the oppositional movement in Russia.
}

power holders, as the critique will follow immediately:

There was one text, which one reader got offended with, a Putin's fan. We wrote that one gay magazine acknowledged Putin as a "queer icon", the most attractive man for homosexuals. So there was [some]one who called us, hard to tell who, and [he/she] was outraged. [...] They got offended only because it was some campaign they [a pro-Kremlin organization] hold, and we took a photo from exactly this campaign. When Putin was at the Baikal, I think, he was top-less there. And after this homosexuals made a rating. And we took the photo, which this pro-Kremlin movement had on one of its posters, and placed it in the newspaper. That's why they were offended (G, editor of international department, male, Russia).

When it comes to the Swedish media, here, on the contrary, it is the politicians' strategic imagemaking resulting in conventional masculinity that becomes a focus of somewhat ironic attention. According to the journalists, essentialist gendering is applied by Swedish politicians in order to draw media attention only in exceptional situations. One of the interviewees talked about how surprised he was when the then Minister of Finance Anders Borg before the 2010 parliamentary elections made an emphasis on what is assumed to be typically masculine behavior. In the opinion of the journalist, it was very unusual for the Swedish context and for the way men politicians are usually expected to behave within it:

He [Anders Borg] found it very important to tell people that he was hunting and that he was really a man living in countryside. And, you know, [he was] taking the prime minister with him, shooting animals and stuff, so that was a bit of a macho thing in Sweden! [...] Maybe it was a tactic: he wanted to build a "man in the countryside" [image]. It was a very male signal, not a very modern signal! I was surprised! (M, political reporter, male, Sweden)

According to the Swedish journalists, such strategies of referring to traditional interpretations of masculinity and femininity in the Swedish context are not just no-win for politicians, they can even be ridiculed by journalists. At least foreign politicians who act in such a way are often perceived by the Swedish media as a target for critique and sarcasms: 
I call [Vladimir Putin] a "macho man.” In my view, he likes to show himself as a strong man. He wants to be fishing in the river without a shirt; he wants to go diving... This you could do in Russia! But if Fredrik Reinfeldt ${ }^{3}$ did the same, we would be laughing! And that is what I say: there is a difference in the society. In Russia you can do it, because it might appeal to more people, in Sweden we would just be laughing! (J, international reporter, male, Sweden)

Thus, intersectionality becomes a double-edged sword. On the one hand, the journalists may use the "matrix of domination" in order to pay attention to the existing power hierarchies, and, thus, draw the public's and the politicians' attention to the subordinated groups of citizens. On the other hand, the categories of gender, sexuality, ethnicity etc. are used by journalists to anchor the critique of the politicians or policies in the public's perceptions of what is accepted and what is not.

\subsection{Intersectionality and the newsroom}

The final theme that occurred in the interviews with the journalists when it comes to intersectionality, was diversity in the newsroom and its importance for the diversity in the content. That was something that mainly the Swedish journalists talked about. According to them, diversity in the newsroom influences both the journalists' attitudes to gender issues and the level of gender-awareness. It has been argued in previous research that journalists' gender does not have a direct influence on the content they produce (Braden, 1996; Djerf-Pierre, 2007; Edström, 2011; Hanitzsch \& Hanusch, 2012; Ross, 2002). The Swedish political journalists themselves, however, are sure that diversity (not only in gender, but also ethnic, cultural, etc.) in the newsroom is the most direct way to overcome gender-blindness. The journalists believe that the mix in the newsroom becomes a basis for discussions, which in turn promote genderawareness along with more sensitivity for other inequalities as well (age, disabilities, ethnicity, etc.):

\footnotetext{
${ }^{3}$ Fredrik Reinfeldt was Prime Minister of Sweden in 2006-2014.
}

I am working in the department with only male colleagues. And it's been the case for years. We have had a male boss for years [...] Don't you think, that we could add some value if it was a more gender mixed newsroom, and a better ethnic and gender mix? I would love to have a young woman with an oriental background, a young smart woman in the newsroom. It would be good for the discussion, and the sources of information, and angles! It's always negative for media to have a newsroom that is too homogeneous (Z, international reporter, female, Sweden).

Thus, the journalists understand the issue of intersectionality in very broad terms, suggesting to speak about the necessity for diversity not only in the media content, but also in the newsroom, allowing for all kinds of perspectives to find the place in the media agenda. 


\section{Conclusions and suggestions for further discussion}

The application of the intersectional approach to the analysis of the interviews with the journalists allowed for a new reading of gendering as a process happening in the framework of other discriminatory and promoting mechanisms related to the "matrix of domination". In my previous research, I suggested a broad definition of gendering as the process that has an ambiguous character (Voronova, 2014). On the one hand, gendering can be based on the journalists' understanding of gender differences as essential, natural, which results in gender stereotyping and unnecessary spotlighting in the content (what I label essentialist gendering). On the other hand, it can be based on the journalists' gender-awareness, on their critical evaluation of the gender hierarchies in politics and society, and then it results in genderaware stories and counter-stereotypes (what I label reflexive gendering).

After re-reading the materials from a perspective of intersectionality, I suggest a similar approach to understanding intersectional matrix in the content of political journalism. When other analytical categories, such as ethnicity, race, religion, sexuality etc. are concerned along with gender, we can speak of the "matrix of domination" in similar terms - in terms of functions that the media content fulfills:

1. Intersectional labelling as othering: applied for critique of (usually foreign) politicians and groups of citizens;

2. Intersectional labelling as promoting of certain groups of citizens or political actors;

3. Intersectional labelling in the context of gender(as well as ethnicity-, sexuality- etc.) aware critique of politicians and policies for not living up to the standards of equality and diversity.

Moreover, I suggest to discuss whether we can similarly to gendering speak about two types of intersectional labelling: essentialist, based on understanding differences between people as "natural", and resulting in maintaining stereotypes and unnecessary spotlighting; and reflexive, based on understanding all categories of the "matrix of domination" as constructed and taking a critical perspective on the power hierarchies based on the intersectional categories, thus, resulting in counterstereotypes and intersectionally-aware stories.

Further on, the role of the media in maintaining or challenging the intersectional hierarchy in the society should be discussed. According to the journalists themselves, the media (especially, the sector of quality press) should represent the world in its diversity, and remind about equality and acceptability of the multiplicity of possible combinations of different categories (such as age, gender, ethnicity etc.) to the public by criticizing the existing hierarchies and mainstreaming the ideal of equality. However, in this task to promote the idea of equal access to political power, the media can either receive support of the state, or face multiple challenges.

The Russian journalists cannot stop or influence the process of narrowing down what is permitted in political communication (Voinova, Resnyanskaya \& Khvostunova, 2007; Voltmer, 2013; Zassoursky, 2004). They in a way turn into an "ambivalent watchdog" (Brants \& Van Kempen, 2002) torn "between the normative ideals of adversarialism, on the one hand, and the constraints of news production, on the other" (Voltmer, 2013: 33). This limits the choice of critical tools that journalists possess. It becomes difficult or almost impossible for the quality press in Russia to criticize the dominant powerful groups for the lack of diversity. The current tendency of nation building and nation branding is based on transmitting the idea of a national culture by referring to its "roots" and "origins", leading to a strengthening of traditionalism and patriarchy (Voronova \& Kalinina, 2015). This tendency is almost fully controlled by the state and supported by the state-controlled media who eagerly discuss, for example, the soon to come collapse of "Gay-ropa" - "gay Europe" with its "alien to the Russian culture concepts of tolerance and multiculturalism" (Zaslavsky, 2014, 8 April), or getting rid of the unwanted by the ruling power holders politicians by labelling them homosexual (as in the case with Yavlinsky). The quality media striving for objectivity want to counteract this 
tendency, but often do not find any other methods than to react in a similar manner: by criticizing the political sphere for being not enough masculine, not enough heterosexual, not enough white (e.g. discussing male politicians as risking to become impotent or homosexual, or blaming Russian politics for acquiring too many features of Asian styles of leadership).

In this sense, the journalists' disenchantment with the politicians and the political process manifests in the form of essentialist intersectional labelling of individual politicians, rather than in critique of the political sphere from intersectional perspective. The essentialist, non-reflexive form the critique takes, only multiplies the inequalities in society. Callamard (2006) speaks about gender-based censorship that manifests in the media's compliance with the traditional gender hierarchy in the society. In a similar way, we can speak of intersectional censorship in Russia. The Russian journalists working for the quality press, on the one hand, wish to counteract this censorship set from above, but, on the other hand, are very limited in the choice of critical tools, and are often trying to play the same card against the state. Thus, by legitimizing essentialist intersectional labelling (talking about its usefulness in critique of politicians, or its commercial benefits) the journalists exercise selfimposed censorship. Unwillingly, they accomplish the politicians' aim to delimit the public sphere.

In the Swedish case, acknowledgement of the media's power by both political journalists and society (Asp, 2012) enables the quality press to maintain diversity in political journalism. The Swedish political journalists appear as critical change agents (see Hanitzsch, 2011), who are constantly involved in a politicized activity of meaning-making (Bacchi \& Eveline, 2010). The journalists demonstrate a clear and quite homogeneous vision of how equal society should be, and aim at promoting diversity. Thus, the Swedish media do not face similar challenges to their Russian colleagues' when it comes to fulfilling their role as a watchdog of the state. They eagerly criticize both the Swedish domestic politicians and political parties, as well as foreign politicians and even entire countries (e.g. Russia, Saudi Arabia) for not living up to the ideals of equality and diversity.

Yet, the Swedish journalists' perception of the current political situation as mature and progressive, can be considered to be problematic, as it limits the critical acknowledgement of the gaps, which seem to be noticed mainly by the female journalists and media experts (e.g. Rönngren, 2014, speaks about the stagnation of development towards gender equality in the Nordic countries). The Swedish journalists already today notice that gender as an issue is disappearing from the political agenda, and is also disappearing from the media agenda. In many ways, it is dictated by the need to pay more attention to other categories in the framework of the "matrix of domination" especially ethnicity. However, it should be important that all the categories in the framework of intersectionality remain on the agenda of intersectionally-aware political journalism, and that the discussions of diversity do not turn to the issues of ethnicity only, but discuss all the hierarchies equally critically.

Thus, it appears that the process of intersectional labelling is highly dependent on the context. When the media power is suppressed by the political power, journalists working for the quality press do not attempt to build restrictions for themselves. Any tools, including essentialist intersectional labelling, become useful for critique of the authorities. When political and media actors, as well as society recognize the power of the quality press, journalists make more responsible choices, have more articulated standards, and pay more attention to the problem of mediation of the matrix of domination.

Finally, intersectionality is connected to commercial logic of the media. In one of the quotations above, one Russian journalist discusses tabloidization as a trend that can harm the ideal of diversity. At the same time, the Swedish journalist who created a "Diversity group" at her previous place of work discussed the economic advantages that her boss, editor-in-chief, saw as a potential outcome of producing more diversity in the content. Thus, commercial logic of the media when it comes to 
intersectional labelling, can also be a double-edged sword, in that it largely depends on the context whether it is the essentialist or reflexive intersectional labelling that will become economically beneficial, and, thus, prioritized by the media. Taking into account the media's in general, and the political journalism in particular dependency on the market, we can along with Edström (2011) once again remember of the individual responsibility of journalists when it comes to the content they produce. The political journalists' involvement in the practices of diversity mainstreaming enhances the democratic development of the society and the position of independent quality press in it. Balanced and diverse content is impossible without intersectionally-aware reporting where the ethical codes serve as a ground, and editorial policies and individual responsibility as beacon lights.

\section{References}

- Allern, S. \& Blach-Orsten, M. (2011). The News Media as a Political Institution: A Scandinavian Perspective. Journalism Studies, 12(1), 92-105.

- Anderson, P.J., Ogola, G. \& Williams, M. (eds.) (2014). The Future of Quality News Journalism: A Cross-Continental Analysis. New York: Routledge.

- Anikina, M. \& Johansson, E. (2013). Russian Journalists: Inclination Toward Moderate Evaluations. In M. Anikina, B. DobekOstrowska \& G. Nygren (eds.). Journalists in Three Media Systems: Polish, Russian and Swedish Journalists about Values and Ideals, Daily Practice and the Future (pp. 69-114). Moscow: Faculty of Journalism, MSU.

- Asp, K. (2012). Synen pe journalisternas makt [A View on the Journalists' Power]. In K. Asp (ed.) Svenska journalister 1989-2011 [Swedish Journalists 1989-2011] (pp. 109-115). Göteborg: JMG, Göteborgs Universitet.

- Bacchi, C. \& Eveline, J. (2010). Mainstreaming Politics: Gendering Practices and Feminist Theory. Adelaide: Adelaide University Press.

- Bergqvist, C. (ed.) (1999). Equal democracies? Gender and Politics in the Nordic Countries. Oslo: Scandinavian University Press.

- Bergqvist, C., Adman, P. \& Jungar, A.-C. (2008). Kön och politik [Sex and Politics]. Stockholm: SNS Förlag.

- Braden, M. (1996). Women Politicians and the Media. Lexington: University Press of Kentucky.

- Brants, K. \& Van Kempen, H. (2002). The Ambivalent Watchdog: The Changing Nature of Political Journalism and its Effects. In R. Kuhn \& E. Neveu (eds.). Political Journalism: New Challenges, New Practices (pp. 168-186). London: Routledge.
- Callamard, A. (2006). Gender Based Censorship and the News Media. Article 19. Retrieved from: http://www.article19.org/data/files/pdfs/p ublications/gender-women-s-day-paper2006.pdf [Accessed June 13th, 2014].

- Code of Conduct for Swedish journalists (n.d.). Retrieved (in Swedish) from: https://www.sjf.se/yrkesfragor/etik/spelregl er-for-press-radio-ochtv (in English): https://www.sjf.se/yrkesfragor/etik/spelregl er-for-pressradio-och-tv/rules-of-professionalconduct [Accessed July 22nd, 2014].

- Code of Ethics for Russian journalists (1994, June). Congress of Russian Journalists. Moscow. Retrieved (in Russian) from: http://www.ruj.ru/about/codex.htm [Accessed July 22nd, 2014].

- Collins, P.H. (2000). Black Feminist Thought: knowledge, consciousness, and the politics of empowerment. New York: Routledge.

- Crawford, M. (2003). Gender and Humor in Social Context. Journal of Pragmatics, 35(9), 1413-1430.

- Dahlgren, P. (2000). Media and Power Transitions in a Small Country: Sweden. In J. Curran and M.-J. Park (eds.) De-Westernizing Media Studies (pp. 251-264). London: Routledge.

- Davis, K. (2008). Intersectionality as Buzzword: A Sociology of Science Perspective on What Makes a Feminist Theory Successful. Feminist Theory, 9(1), 67-85.

- Djerf-Pierre, M. (2007). The Gender of Journalism: The Structure and Logic of the Field in the Twentieth Century. Nordicom Review, 28 (Jubilee Issue), 81-104.

- Djerf-Pierre, M. (2011). The Difference Engine: Gender equality, Journalism and the 
Good Society. Feminist Media Studies, 11(1), 4351.

- $\quad$ Edström, M. (2011). Is there a Nordic Way? A Swedish Perspective on Achievements and Problems with Gender Equality in Newsrooms. Medijske studije, 2(3-4), 64-75.

- Ekecrantz, J. (2005). News Paradigms, Political Power and Cultural Contexts in 20th Century Sweden. In S. Hoyer \& H. Pöttker (eds.) Diffusion of the News Paradigm 1850-2000 (pp. 93-104). Göteborg: Nordicom.

- Falk, E. (2008). Women for President: Media Bias in Eight Campaigns. Urbana: University of Illinois Press.

- Fiig, C. et.al. (2015). Panel for Media, Democracy and Politics in a Perspective of Intersectionality, Section for Intersectionality, Citizenship and Multiculturalism. European Conference on Politics and Gender (ECPG) 2015, June 11-13, Uppsala University.

- Freidenvall, L. (2006). Vägen till Varannan damernas: Om kvinnorepresentaion, kvotering och kandidaturval i svensk politik 1970-2002 [The Way to Gender Equality in Political Sphere: About Women's Representation, Affirmative Action and Choice of Candidates in the Swedish Politics 1970-2002]. Stockholm: Statsvetenskapliga institutionen, Stockholm University.

- Gallagher, M. (2005). Who Makes the News? Global Media Monitoring Project 2005. London: WACC.

- Getting the Balance Right: Gender Equality in Journalism (2009), International Federation of Journalists, Brussels. Retrieved from: http: / / portal.unesco.org/ci/en/files/28397/ 12435929903gender_booklet_en.pdf/gender _booklet_en.pdf [Accessed July 21st, 2014].

- Gill, R. (2007). Gender and the Media. Cambridge: Polity Press.

- Global Gender Gap Index (2014). Retrieved from: http://reports.weforum.org/globalgender-gap-report-2014/rankings/ [Accessed November $\left.15^{\text {th }}, 2015\right]$.

- Global Media Monitoring Project Report (GMMP) (2010). Retrieved from: http: / / www.whomakesthenews.org/images/ reports_2010/global/gmmp_global_report_e n.pdf [Accessed November 1st, 2013].

- Hallin, D.C. \& Mancini, P. (2004). Comparing Media Systems: Three Models of Media and Politics. Cambridge: Cambridge University Press.
- Hanitzsch, T. (2011). Populist Disseminators, Detached Watchdogs, Critical Change Agents and Opportunist Facilitators: Professional Milieus, the Journalistic Field and Autonomy in 18 Countries. International Communication Gazette, 73(6), 477-494.

- Hanitzsch, T. \& Hanusch, F. (2012). Does gender determine journalists' professional views? A reassessment based on cross-national evidence. European Journal of Communication, 27(3), 257-277.

- Hanitzsch, T. et al. (2010). Modeling Perceived Influences on Journalism: Evidence from a Cross-National Survey of Journalists. Journalism and Mass Communication Quarterly, 87(1), 7-24.

- Holli, A.M., Magnusson, E. \& Rönnblom, M. (2005). Critical Studies of Nordic Discourses on Gender and Gender Equality. NORA Nordic Journal of Feminist and Gender Research, 13(3), 148-152.

- Hultén, G. (2015). Race Place Shape: A Case Study of Contested Racialized Boundaries of Belonging, Embodiment and Gender in Swedish Alternative Media. Conference paper presented at the European Conference on Politics and Gender (ECPG) 2015, June 1113, Uppsala University.

- Inglehart, R. \& Norris, P. (2003). Rising Tide: Gender Equality and Cultural Change Around the World. New York: Cambridge University Press.

- Jensen, K.B. (2002). Designing Qualitative Studies. In K.B. Jensen (ed.). A Handbook of Media and Communication Research: Qualitative and Quantitative methodologies. London: Routledge.

- Jönsson, A.M. (2004). Samma nyheter eller likadana? Studier av mångfald i svenska TV-nyheter [Same News or Similar? Studies of Diversity in Swedish Television News]. Doctoral dissertation. Göteborg: Göteborgs Universitet.

- Kalinina, E. and Voronova, L. (2011). ”Where Men and Women Make a Jest, a Problem Lies Concealed:" A Multilayered Analysis of Russian Infotainment TV Programs Projectorparishilton and Devchata. In O. Smirnova (ed.) Gender i SMI 2010 [Gender and Media 2010] (pp. 105-133). Moscow: Faculty of Journalism, Moscow State University.

- Karam, A. (ed.) (1998). Women in Parliaments: Beyond Numbers. Stockholm: International 
Institute for Democracy and Electoral Assistance (IDEA).

- Kay, R. (ed.) (2007). Gender, Equality and Difference During and After State Socialism. Basingstoke: Palgrave Macmillan.

- Klaus, E. (2009). Media Systems, Equal Rights and the Freedom of Press: Gender as a Case in Point. In A. Czepek, M. Hellwig \& E. Novak (eds.) Press Freedom and Pluralism in Europe: Concepts and Conditions (pp. 101-114). Bristol: Intellect.

- Koltsova, O. (2001). News Production in Contemporary Russia: Practices of Power. European Journal of Communication, 16(3), 315335.

- Lindlof, T.R. and Taylor, B.C. (2002). Qualitative Communication Research Methods (2nd edn.). Thousand Oaks: Sage.

- Löfgren Nilsson, M. (2010). "Thinkings" and "Doings" of Gender: Gendering Processes in Swedish Television News Production. Journalism Practice, 4(1), 1-16.

- Lünenborg, M. \& Fürsich, E. (2014). Media and the Intersectional Other: The Complex Negotiation of Migration, Gender, and Class on German Television. Feminist Media Studies, 14(6), 959-975.

- Lykke, Nina (2010). Feminist Studies: A Guide to Intersectional Theory, Methodology and Writing. New York: Routledge

- McCall, L. (2005). The Complexity of Intersectionality. Signs, 30(3), 1771-1800.

- Mission Possible: A Gender and Media Advocacy Toolkit (2008). World Association for Christian Communication and Global Media Monitoring Project. Retrieved from: http: / /www.wsscc.org/sites/default/files/p ublications/wacc_mission_possible_2008_en. pdf [Accessed July 22nd, 2014].

- Norris, P. (ed.) (1997). Women, Media and Politics. New York: Oxford University Press.

- Nygren, G. \& Appelberg, J. (2013). Swedish Journalists - A Profession in Decline? In M. Anikina, B. Dobek-Ostrowska \& G. Nygren (eds.) Journalists in Three Media Systems: Polish, Russian and Swedish Journalists about Values and Ideals, Daily Practice and the Future (pp. 115164). Moscow: Faculty of Journalism, MSU.

- Osika, I. (2008). Kvinna i världens mest jämställda land: En handbok om kvinnors rättigheter framtagen av CEDAW-nätverket och Sveriges Kvinnolobby [Woman in the World's Most Equal Coun- try: A Handbook on Women's Rights]. Stockholm: Sveriges kvinnolobby.

- Pasti, S. \& Nordenstreng, K. (2013). Paradoxes of Journalistic Profession: Case of Russia in the Context of the BRICS Countries. In E. Vartanova (ed.) World of Media 2012: Yearbook of Russian Media and Journalism Studies (pp. 243-268). Moscow: MediaMir.

- Peters, B. (2001). Equality and Quality: Setting Standards for Women in Journalism. IFJ Survey on the Status of Women Journalists. Brussels: International Federation of Journalists. Retrived from: http: / /www.ifj.org/assets/docs/231/007/a6 1e5e7-2c52b07.pdf [Accessed February 27th, 2014].

- Posadskaya, A. (1993). Zhenskoe izmerenie sotsial'noj transformatsii: ot Foruma $\mathrm{k}$ Forumu' [Women's Dimension of Social Transformation: From Forum to Forum]. In Materialy Vtorogo Nezavisimogo Zhenskogo Foruma [Proceedings of the Second Women's Independent Forum] (pp. 13-19). Moscow: CGI IESPN RAN.

- Recommendation CM/Rec (2013). Council of Europe, Committee of Ministers to member States on gender equality and media, adopted by the Committee of Ministers on July 10th, 2013. Retrieved from: https: / / wcd.coe.int/ViewDoc.jsp?id=208734 3\#P5_104 [Accessed July 21st, 2014].

- Rigoni, I. (2012). Intersectionality and mediated cultural production in a globalized post-colonial world. Ethnic and Racial Studies, Special issue "Gender, Migration and the Media”, 35(5), 834-849.

- Roosvall, A. \& Widestedt, K. (2015). Medier och intersektionalitet. In A. Hirdman \& M. Kleberg (eds.) Mediers känsla för kön: feministisk medieforskning (pp. 35-53). Göteborg: Nordicom.

- Ross, K. (2002). Women, Politics, Media: Uneasy Relations in Comparative Perspective. Cresskill, N. J.: Hampton Press.

- Ross, K. (2010). Gendered Media: Women, Men and Identity Politics. Lanham: Rowman \& Littlefield Publishers.

- Rönngren, J. (2014). Media's Gender Equality Work Has Stagnated. Nordic Information on Gender (NIKK). Retrieved from: http://www.nikk.no/en/news/mediasgender-equality-work-has-stagnated/ [Accessed July 11th, 2014]. 
- Sreberny-Mohammadi, A. \& van Zoonen, L. (eds) (2000). Gender, Politics and Communication. Cresskill, N.J.: Hampton Press.

- Strömbäck, J. (2009). Makt, medier och samhälle: en introduktion till politisk kommunikation [Power, Media and Society: An Introduction to Political Communication]. Stockholm: SNS Förlag.

- Temkina, A. \& Zdravomyslova, E. (2014). Gender's Crooked Path: Feminism Confronts Russian Patriarchy. Current Sociology, 62(2), 253-270.

- van Zoonen, L. (1994). Feminist Media Studies. London: Sage.

- van Zoonen, L. (1998). A Professional, Unreliable, Heroic Marionette (M/F): Structure, Agency and Subjectivity in Contemporary Journalisms. European Journal of Cultural Studies, 1(1), 123-143.

- Vartanova, E. (2013). Postsovetskie transformatsii rossijskikh SMI i zhurnalistiki [Post-Soviet Transformations of the Russian Media and Journalism]. Moscow: MediaMir.

- Wiik, J. (2014). Towards the Liberal Model: The Professional Identity of Swedish Journalists. Journalism Practice, 1-10.

- Voinova, E.A., Resnyanskaya, L.L. \& Khvostunova, O.I. (2007). SMI i politika [Mass Media and Politics]. Moscow: Aspect Press.

- Voltmer, K. (2013). The Media in Transitional Democracies. Cambridge: Polity Press.
- Voronova, L. (2014). Gendering in Political Journalism: A Comparative Study of Russia and Sweden. Doctoral dissertation. Örebro: Örebro University.

- Voronova, L. \& Kalinina, E. (2015). Introduction. Gender and Post-Soviet Discourses. In L. Voronova, E. Kalinina \& U. Dahl (eds.) Gender and Post-Soviet Discourses. Special issue. Baltic Worlds, 1-2, 36-37.

- Widestedt, K. (2008). Issues of gender equality and diversity in broadcast news policy. Nordicom Review, 29(1), 45-62.

- Zaslavsky, G. (2014, 8 April). "Rossiya - ne Evropa": "Osnovy gosudarstvennoj politiki" vyzvali ostruyu polemiku ["Russia is not Europe": "The fundamentals of state cultural policy" caused considerable controversy]. Vesti $F M$. Retrieved (in Russian) from: http: / / radiovesti.ru/article/show/article_id/ 132931 [Accessed November 15 ${ }^{\text {th }}, 2015$ ].

- Zassoursky, I. (2004). Media and Power in PostSoviet Russia. New York: M.E. Sharpe.

- Zdravomyslova, O.M. (2003). Sem'ya i obschestvo: gendernoe izmerenie rossijskoj transformatsii [Family and Society: Gender Dimension of the Russian Transformation]. Moscow: Editorial URSS.

\section{Forma de Citación}

VORONOVA, Liudmila: From gendering to intersectional labelling. Russian and Swedish political journalists' perspective on discriminating and promoting mechanisms in the media content. Revista Communication Papers, N ${ }^{\circ} 7$, páginas 64 a 79. Departamento de Filología y Comunicación de la Universidad de Girona. Recuperado el de de 2 de: http://www.communicationpapers.es 